\title{
EFFECTS OF SALINITY ON THE SURVIVAL AND HISTOLOGY OF OYSTERS Crassostrea gasar (ADANSON, 1757)
}

\author{
EFEITOS DA SALINIDADE NA SOBREVIVÊNCIA E HISTOLOGIA DE OSTRAS \\ Crassostrea gasar (ADANSON, 1757)
}

\section{Aline HORODESKY ${ }^{1}$; Gisela Geraldine CASTILHO-WESTPHAL ${ }^{2}$; Nathieli COZER $^{3}$, Vitor Gomes ROSSI ${ }^{4}$; Antonio OSTRENSKY ${ }^{5}$}

1. PhD - Postgraduation in Zoology - Federal University of Paraná - UFPR - Brazil, Integrated Group of Aquaculture and Environmental Studies, Federal University of Paraná, Curitiba, Paraná, Brazil. Corresponding author: aline.horo@ yahoo.com.br. 2. PhD - Postgraduation in Zoology - Federal University of Paraná - UFPR - Brazil, Integrated Group of Aquaculture and Environmental Studies, Federal University of Paraná, Curitiba, Paraná, Brazil. 3. PhD - Postgraduation in Animal Science - Federal University of Paraná - UFPR - Brazil, Integrated Group of Aquaculture and Environmental Studies, Federal University of Paraná, Curitiba, Paraná, Brazil. 4. Master's degree in Animal Science - Federal University of Paraná - UFPR - Brazil, Integrated Group of Aquaculture and Environmental Studies, Federal University of Paraná, Curitiba, Paraná, Brazil. 5. PhD in Zoology, Teacher - Federal University of Paraná - UFPR - Brazil, Integrated Group of Aquaculture and Environmental Studies, Federal University of Paraná, Curitiba, Paraná, Brazil.

\begin{abstract}
Water salinity is among the most important factors influencing the distribution, abundance, growth, and survival of Crassostrea gasar, an important aquaculture resource grown in estuarine environments in diverse regions of the world. The goal of the present work was to evaluate the effects of different salinities on survival and the tissues of $C$. gasar under laboratory conditions. Two experiments were performed using adult oysters from five marine farms located in the bay of Guaratuba, Brazil. In Experiment 1, the daily survival rates were evaluated after the oysters were submitted to gradual acclimatization at salinities ranging from 0 to $65 \mathrm{gL}^{-1}$ and maintained in the laboratory without feeding for up to 365 days. In Experiment 2, the oysters were exposed to salinity from 0 to $50 \mathrm{gL}^{-1}$ for up to 30 days without feeding and possible histological alterations caused by salinity were assessed. Three tolerance ranges of $C$. gasar to salinity were identified: "Optimal" (between 4 and $40 \mathrm{gL}^{-1}$ ), "Tolerable" (between 2.1 and 3.9 and between 41 and $50 \mathrm{gL}^{-1}$ ) and "Intolerable" (less than 2 and greater than $50 \mathrm{gL}^{-1}$ ). No evidence of histological alterations was observed in oysters exposed to the different salinities.
\end{abstract}

KEYWORDS: Estuary. Histopathology. Mortality. Oyster culture.

\section{INTRODUCTION}

Oysters are widely cultivated commercially in estuarine environments that feature great seasonal and even daily fluctuations of several environmental variables (Pereira C. S. 2003, Vilanova and Chaves 1988). In these environments, while the salinity is typically less than that of natural seawater, it also varies temporally and spatially and can, in certain instances, become hypersaline in specific regions where evaporative water loss is high and freshwater and tidal inputs are negligible (Potter et al. 2010). Therefore, salinity is considered the most important factor in the distribution, abundance, growth, and survival oyster (Brown and Hartwick 1988, Casas et al. 2017, Tolley et al. 2006, Wells 1961).

Salinity can directly affect the physiological processes of mollusc larvae, interfering in their feeding capacity, duration of the planktonic phase, and ability to select settlement sites (Siddall 1982). In juvenile and adult oysters, the ability to support variations of salinity is related to their osmoconforming efficiency (Galtsoff 1964, Shumway 1996).

Similar to most bivalves, oysters do not have sophisticated osmoregulation mechanisms (Méthé 2015). In fact, they do not regulate but instead dilute/concentrate the extracellular osmolarity through the rapid increase/decrease in cellular volume in response to the flow of water produced by osmotic stress (Pierce 1982). In this way, the extracellular fluid remains isosmotic in relation to the fluid present in the mantle cavity (Loosanoff 1953).

The capacity of osmotic equilibrium with the environment differs significantly between oysters of the same species that inhabit different aquatic biotopes, due primarily to population polymorphisms (Pierce 1982). Despite the wide tolerance that the oysters present, it is known that tissue changes and drastic reductions in oyster survival and growth rates can occur depending on the amplitude and velocity of salinity variation 
(Downs et al. 2009, La Peyre et al. 2003, Levinton et al. 2011, Parada et al. 2012).

$$
\text { Crassostrea gasar (synonymy = }
$$

Crassostrea brasiliana) is present on the West coast of Africa from Senegal to Angola (Afinowi 1984), as well as on the Atlantic coast of South America, ranging from French Guiana to southern Brazil (Baldan and Bendhack 2009, Lapègue et al. 2002). This species is popularly known as the mangrove oyster because it fixes itself to mangrove roots in the intertidal zone, though it settles directly on the bottom substrate in the infralittoral zone (Areias 2012). Crassostrea gasar is the main native oyster species cultivated in Brazil (Castilho-Westphal and Ostrensky 2017, Legat et al. 2017, Lopes et al. 2013).

This study aimed to evaluate the effects of different salinities on C. gasar under laboratory conditions, particularly their influence on the survival rates and possible tissue alterations in these animals.

\section{MATERIAL AND METHODS}

In 2015 two independent experiments were conducted: Experiment 1 - Effects of salinity on oyster survival and Experiment 2 - Histological effects of salinity.

\section{Obtaining animals}

The oysters used in the experiments $(n=$ 438) were obtained from five marine farms located in the Bay of Guaratuba, Paraná State, Brazil (Lat. $25^{\circ} 83^{\prime} \mathrm{S}$, Long. $48^{\circ} 57^{\prime} \mathrm{W}$ ). The oysters used in the experiment 1 were obtained in February of 2014 and the others used in the experiment 2 were obtained in May of 2015.

At the time of animal collection in the cultivation structures (Japanese lanterns), the temperature (analogue thermometer Incoterm, Brazil) and salinity (Instrutemp optical refractometer, Brazil) were measured. The values recorded for these parameters were subsequently used as a reference to guide the acclimatization of the animals in the laboratory.

After collection, the oysters were washed using a high-pressure washer to remove sediment and epibionts. The animals were later stored in thermal boxes and transported to the Aquatic Organisms Research Laboratory (LAPOA), which belongs to the Integrated Group of Aquaculture and Environmental Studies (GIA) of the Federal University of Paraná, Curitiba, Paraná, Brazil (Lat. $25^{\circ} 24^{\prime} 47.70 "$ S, Long. 49¹4'52.82"O).

\section{Common procedures for experiments 1 and 2}

The oysters were acclimatized in tanks with a capacity of $500 \mathrm{~L}$, filled with seawater of the same salinity $\left(27 \mathrm{gL}^{-1}\right)$ observed at the time that the animals were collected from the cultivation structures. The oysters were maintained in these tanks for five days to acclimatize to the conditions. After this period, the salinity of the water was altered every two days in $5 \mathrm{gL}^{-1}$ adding freshwater or sea salt (Romani S/A, Brazil). The acclimation was performed under constant aeration and temperature of $25 \pm 1.0^{\circ} \mathrm{C}$.

None of the animals was fed during the experiment. The following abiotic variables were monitored daily throughout the experiment: dissolved oxygen $(\mathrm{mg} / \mathrm{L})$ and temperature $\left({ }^{\circ} \mathrm{C}\right)$ (digital oximeter YSITM Pro 20, USA); salinity ( $\mathrm{gL}^{-}$ 1) (Instrutemp ${ }^{\mathrm{TM}}$ refractometer, Brazil); $\mathrm{pH}(\mathrm{pH}$ metre Sensoglass ${ }^{\mathrm{TM}}$ SP1400, Brazil); total ammonia $\left(\mathrm{mg} / \mathrm{L}\left(\mathrm{NH}_{3}+\mathrm{NH}_{4}^{+}\right)-\mathrm{N}\right)$ and nitrite concentrations $\left(\mathrm{mg} / \mathrm{L} \quad \mathrm{NO}_{2}^{-}-\mathrm{N}\right)$ obtained by the colourimetric method (APHA, 2005) by reading the samples by spectrometry (Molecular Devices TM ExpectraMax M2, USA). After these variables were measured, $100 \%$ of the water was renewed in the experimental units. The water used in the experiment was previously chlorinated with $12 \%$ sodium hypochlorite, neutralized with sodium thiosulphate and later filtered through a $20 \mu \mathrm{m}$ mesh net.

\section{Experiment 1}

The animals used in this experiment had a mean ( \pm standard deviation) weight of $52.5 \pm 13.8 \mathrm{~g}$, height (dorsoventral axis) of $68 \pm 8 \mathrm{~mm}$, length (anteroposterior axis) of $48 \pm 7 \mathrm{~mm}$ and width (transverse axis) of $22 \pm 4 \mathrm{~mm}$ (measurements based on Galtsoff (1964)).

The tests were performed in 42 experimental units composed of $5 \mathrm{~L}$ plastic containers filled with water, which were kept in water-bath systems mounted in 1,000 L water tanks. With the aid of the heaters and thermostats, these systems enabled to maintain the water temperature throughout the experiment $\left(25 \pm 1.0^{\circ} \mathrm{C}\right)$.

Fourteen treatments $(0,1,2,3,4,5,10,25$, $35,40,45,50,55$, and $\left.65 \mathrm{gL}^{-1}\right)$ were tested, all of which were performed in triplicate. In each experimental unit, four oysters were placed, totalling 12 oysters per treatment and 168 animals tested in this experiment.

The oysters were observed daily three times a day ( 8 am, $1 \mathrm{pm}$ and $7 \mathrm{pm}$ ) to identify any dead individuals. Oysters with open shells that did not 
show any reaction to a light beating in their shell using a solid object, such as the shell of another oyster, were considered dead. Dead individuals were immediately removed from the system. The experiment lasted 365 days.

The data for this experiment were analysed using Statistica 10.0 software (StatSoft TM). First, the normality of the data was tested using the Shapiro \& Wilk test. With the confirmation of the data violating the assumptions of normality and being non-parametric ( $\mathrm{p}>0.05)$, a Kruskal-Wallis $\mathrm{H}$ test was performed to evaluate the influence of different salinities on oyster survival.

Based on the "Ecological Tolerance Law" (Shelford 1914) and on the average survival time of the oysters in a given salinity, three tolerance classes were determined: Optimal (survival time $\geq$ 50 days), Tolerable (survival time between 25 and 50 days) and Intolerable (survival time $\leq 25$ days).

\section{Experiment 2}

Five treatments $\left(0,10,25,40\right.$ and $\left.50 \mathrm{gL}^{-1}\right)$ were tested, all of which were performed in triplicate. The experiment was conducted in laboratory in 15 experimental units, like those used in experiment 1 , each containing 18 oysters (total of 270 animals), with a mean weight of $62.7 \pm 10.8 \mathrm{~g}$, height of $71 \pm 7 \mathrm{~mm}$, length of $49 \pm 7 \mathrm{~mm}$ and width of $22 \pm 7 \mathrm{~mm}$. Six oysters collected directly from commercial cultivation structures were used as a reference (Control) for evaluating the tissue changes observed subsequently in the experimental treatments.

The experimental units were inspected daily to evaluate the presence of dead oysters. Postmortem alterations compromise the quality of the samples in several ways, such as making tissue analyses infeasible by altering cellular morphology, causing tissue disorganization or masking injuries, and compromising the accuracy of analyses. Consequently, all animals killed during the experiment were discarded.

After 0, 5, 15 and 30 days of exposure, until six oysters from each experimental unit were collected and submitted to routine histological processing involving: i) biometric analysis; ii) opening of the shells for the collection of tissues; iii) tissue fixation in ALFAC - Davidson solution (33\% ethanol 95\%, 22\% formaldehyde, $11.5 \%$ acetic acid and $33.5 \%$ distilled water) for 48 hours; iv) separation of fragments with approximately $1 \mathrm{~cm}^{3}$ of the gonads, gills, mantle and digestive tract (labial palps, digestive gland and stomach); v) exposure of the material to a growing series of alcohols; vi) diaphanization in xylol and histological paraffin impregnation at $56^{\circ} \mathrm{C}$; vii) sectioning on a rotating microtome, with cuts of $5 \mu \mathrm{m}$ thickness; and viii) mounting of permanent slides, stained with Harris haematoxylin and eosin (HE), according to methodology proposed by Behmer et al. (1976).

The total area of five blade fields for each organ and five gills of each animal, randomly defined, were analysed under an optical microscope (Olympus $^{\mathrm{TM}}$ CX40, USA), using a total magnification of 400x. The tissue alterations were photomicrographed with the aid of a digital camera (ToupCam LCMOS14000KPA, ToupTek ${ }^{\mathrm{TM}}$, China) and image capture software (ToupView 3.7, ToupTek ${ }^{\mathrm{TM}}$, China).

After data were confirmed to violate the assumptions of normality, analyses were performed using the non-parametric Shapiro \& Wilk test and Kruskal-Wallis $\mathrm{H}$ tests. These tests evaluated if there were differences between the tissue alterations in each salinity and if there were differences in the prevalence of pathogens in each experimental treatment.

\section{RESULTS}

\section{Effects of salinity on oyster survival}

There was significant variation in water quality variables measured among the different experimental treatments $(\mathrm{p}<0.05)$. However, extreme values remained within the recommended limits for the survival of bivalve molluscs (Table 1).

Although the oysters did not receive any food during the experimental period, $23.2 \%$ of individuals exposed to a salinity of $5 \mathrm{gL}^{-1}$, and $25 \%$ of those exposed to a salinity of $10 \mathrm{gL}^{-1}$ remained alive for 365 days. The "Optimum" range of salinity was 4 to $40 \mathrm{gL}^{-1}$; the "Tolerable" range was between 2.1 and 3.9, and 41 and $49 \mathrm{gL}^{-1}$; and the "Intolerable" range was below $2 \mathrm{gL}^{-1}$ and above 50 $\mathrm{gL}^{-1}$ (Figure1).

\section{Effect of salinity on oyster tissue}

Deaths of individuals were recorded in all treatments, which made it impossible for all animals tested to have their tissues analysed through histology (Table 2). 
Table 1. Measured (mean [min-max]) and references values for the water quality variables throughout the experiment. Different lowercase letters indicate significant differences $(\mathrm{p}<0.05)$ among treatments.

\begin{tabular}{|c|c|c|c|c|}
\hline \multirow{3}{*}{$\begin{array}{l}\text { Salinity } \\
\left(\mathrm{gL}^{-1}\right)\end{array}$} & $\begin{array}{l}\text { Total ammonia-N } \\
\text { (mg/L TA-N) }\end{array}$ & $\begin{array}{l}\text { Nitrite }-\mathrm{N} \\
\left(\mathrm{mg} / \mathrm{L} \mathrm{NO}{ }_{2}^{-} \mathrm{N}\right)\end{array}$ & $\begin{array}{l}\text { Dissolved } \\
(\mathrm{mg} / \mathrm{L})\end{array}$ & ${ }^{\text {oxygen }} \mathrm{pH}$ \\
\hline & \multicolumn{4}{|c|}{ Reference value } \\
\hline & $<7.2 \dagger$ & $<345.1+$ & $>3 \S$ & 6.7-8.7I \\
\hline \multirow{2}{*}{0} & $1.1^{\mathrm{cd}}$ & $0.2^{\mathrm{bcd}}$ & $6.9^{\mathrm{bc}}$ & $7.4^{\mathrm{abc}}$ \\
\hline & $(0.01-5.5)$ & $(0.00-2.2)$ & $(5.5-8.3)$ & $(6.4-8.6)$ \\
\hline \multirow{2}{*}{1} & $1.2^{\mathrm{cd}}$ & $7.3^{\mathrm{cd}}$ & $7.2^{\mathrm{bcd}}$ & $7.6^{\mathrm{abc}}$ \\
\hline & $(0.04-5.8)$ & $(0.6-22.1)$ & $(6.3-8.3)$ & $(6.9-8.1)$ \\
\hline \multirow{2}{*}{2} & $0.7^{\mathrm{bcd}}$ & $9.9^{\mathrm{cd}}$ & $7.2^{\mathrm{abcd}}$ & $7.6^{\mathrm{abc}}$ \\
\hline & $(0.00-2.2)$ & $(0.1-24.2)$ & $(6.2-8.3)$ & $(7.0-8.0)$ \\
\hline \multirow{2}{*}{3} & $0.8^{\mathrm{bc}}$ & $11.1^{\mathrm{cd}}$ & $7.8^{\mathrm{cd}}$ & $7.5^{\mathrm{abc}}$ \\
\hline & $(0.01-6.7)$ & $(0.06-20.6)$ & $(6.3-8.9)$ & $(6.7-8.4)$ \\
\hline \multirow{2}{*}{4} & $0.5^{\mathrm{bc}}$ & $6.6^{\mathrm{cd}}$ & $7.7^{\mathrm{cd}}$ & $7.3^{\mathrm{ab}}$ \\
\hline & $(0.01-6.0)$ & $(0.01-20.5)$ & $(6.2-8.9)$ & $(6.3-8.2)$ \\
\hline \multirow{2}{*}{5} & $0.6^{\mathrm{bc}}$ & $1.4^{\mathrm{cd}}$ & $7.3^{\mathrm{bc}}$ & $6.9^{\mathrm{cd}}$ \\
\hline & $(0.01-5.6)$ & $(0.01-10.2)$ & $(5.0-9.9)$ & $(6.0-9.9)$ \\
\hline \multirow{2}{*}{10} & $0.7^{\mathrm{bc}}$ & $1.6^{\mathrm{cd}}$ & $7.2^{\mathrm{bc}}$ & $7.1^{\mathrm{cd}}$ \\
\hline & $(0.01-6.4)$ & $(0.01-13.3)$ & $(5.1-8.9)$ & $(5.5-8.8)$ \\
\hline \multirow{2}{*}{25} & $0.3^{\mathrm{abc}}$ & $0.2^{\text {cd }}$ & $7.3^{\mathrm{bc}}$ & $7.3^{\mathrm{bc}}$ \\
\hline & $(0.03-2.9)$ & $(0.00-9.6)$ & $(5.1-8.3)$ & $(6.5-8.2)$ \\
\hline \multirow{2}{*}{35} & $0.2^{\mathrm{abc}}$ & $0.2^{\mathrm{abc}}$ & $7.3^{\mathrm{bc}}$ & $7.5^{\mathrm{bc}}$ \\
\hline & $(0.02-1.7)$ & $(0.00-0.8)$ & $(5.5-8.3)$ & $(6.4-8.7)$ \\
\hline \multirow{2}{*}{40} & $0.2^{\mathrm{abc}}$ & $0.2^{\mathrm{abc}}$ & $7.2^{\mathrm{abc}}$ & $7.7^{\mathrm{bc}}$ \\
\hline & $(0.03-3.2)$ & $(0.00-0.9)$ & $(4.8-8.3)$ & $(6.5-8.7)$ \\
\hline \multirow{2}{*}{45} & $0.4^{\mathrm{bcd}}$ & $0.3^{\mathrm{bc}}$ & $7.1^{\mathrm{abc}}$ & $7.9^{\mathrm{bcd}}$ \\
\hline & $(0.04-3.1)$ & $(0.01-1.0)$ & $(5.2-8.9)$ & $(6.6-8.8)$ \\
\hline \multirow{2}{*}{50} & $0.2^{\mathrm{cd}}$ & $0.2^{\mathrm{bc}}$ & $7.1^{\mathrm{abc}}$ & $7.8^{\mathrm{bcd}}$ \\
\hline & $(0.02-1.4)$ & $(0.01-0.8)$ & $(5.3-8.2)$ & $(6.7-8.9)$ \\
\hline \multirow{2}{*}{55} & $0.5^{\mathrm{bcd}}$ & $0.2^{\mathrm{bc}}$ & $7.1^{\mathrm{abc}}$ & $7.3^{\mathrm{cd}}$ \\
\hline & $(0.03-3.4)$ & $(0.01-1.0)$ & $(5.5-7.9)$ & $(6.4-8.6)$ \\
\hline \multirow{2}{*}{65} & $0.6^{\mathrm{bcd}}$ & $2.2^{\mathrm{bcd}}$ & $7.2^{\mathrm{abc}}$ & $7.3^{\mathrm{cd}}$ \\
\hline & $(0.02-3.8)$ & $(0.01-4.6)$ & $(6.2-8.6)$ & $(6.7-8.0)$ \\
\hline
\end{tabular}

$\dagger$ C. rhizophorae (Guzenski 1996)

$\$$ Argopecten irradians (Widman et al. 2008)

$\S$ Crassostrea sp. (Mello 2007)

II Crassostrea gigas (Morales 1986) 


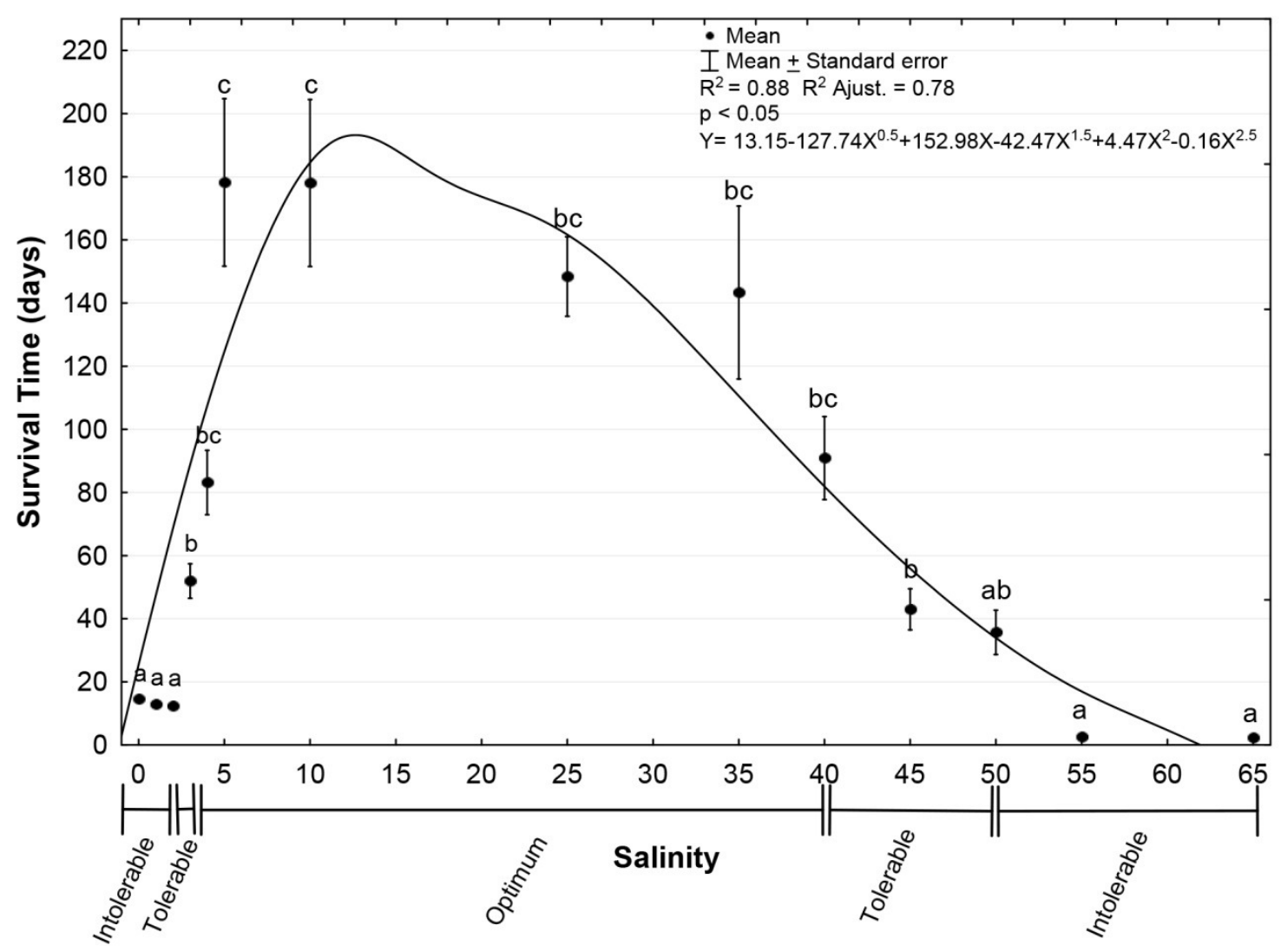

Figure 1. Adjusted survival curve and tolerance ranges of Crassostrea gasar to salinity. Different lowercase letters indicate significant differences $(\mathrm{p}<0.05)$ between the experimental treatments (salinities), using the Kruskal-Wallis $\mathrm{H}$ test.

Table 2. Total number of oysters analysed during the experimental period in different treatments (salinities).

\begin{tabular}{|c|c|c|c|c|c|c|c|c|c|c|c|c|}
\hline \multirow{2}{*}{$\begin{array}{l}\text { Salinity } \\
\left(\mathrm{gL}^{-1}\right)\end{array}$} & \multicolumn{12}{|c|}{ Period (days) } \\
\hline & \multicolumn{3}{|c|}{$\begin{array}{l}\mathbf{0} \\
\text { (Control) }\end{array}$} & \multicolumn{3}{|c|}{1 to 5} & \multicolumn{3}{|c|}{6 to 15} & \multicolumn{3}{|c|}{16 to 30} \\
\hline & $\mathbf{L}$ & D & $\mathbf{A}$ & $\mathbf{L}$ & D & $\mathbf{A}$ & $\mathbf{L}$ & D & $\mathbf{A}$ & $\mathbf{L}$ & D & $\mathbf{A}$ \\
\hline 0 & 6 & 0 & 6 & 15 & 39 & 15 & 0 & 0 & 0 & 0 & 0 & 0 \\
\hline 10 & 6 & 0 & 6 & 54 & 0 & 18 & 36 & 0 & 18 & 14 & 4 & 14 \\
\hline 25 & 6 & 0 & 6 & 54 & 0 & 18 & 36 & 0 & 18 & 6 & 12 & 6 \\
\hline 40 & 6 & 0 & 6 & 54 & 0 & 18 & 36 & 0 & 18 & 10 & 8 & 10 \\
\hline 50 & 6 & 0 & 6 & 54 & 0 & 18 & 8 & 28 & 8 & 0 & 0 & 0 \\
\hline
\end{tabular}

$\mathrm{L}=$ Alive; $\mathrm{D}=$ Dead; $\mathrm{A}=$ Analysed

Histological analysis revealed three types of alterations in the oysters: the presence of stress indicator cells, tissue changes, and the presence of pathogens (Figure 2; Table 3). However, none of these factors was correlated with salinity $(p>0.05)$, either in relation to the total numbers of alterations, or in relation to the organs analysed or the periods of exposure. Significant differences $(\mathrm{p}<0.05)$ were observed only in relation to Nematopsis sp. and
Rickettsia-like organism (RLO) pathogens (Table 4).

There was only a difference between two concentrations for each pathogen, which does not represent an indication that salinity influences the number of pathogens, since there was no pattern. That is, there was no increase or decrease of pathogens proportionate to the increase or decrease of salinity. 
Table 3. Pathogens observed in oyster (Crassostrea gasar) tissues exposed to different salinities.

\begin{tabular}{|c|c|c|c|}
\hline Pathogens & Description & Organ & Salinity $\left(\mathrm{gL}^{-1}\right)$ \\
\hline Nematopsis sp. & $\begin{array}{lr}\text { Sporozoa. } & \text { Genera of } \\
\text { protozoic, } & \text { gregarine }\end{array}$ & $\begin{array}{l}\text { Gills, } \\
\text { stomach, } \\
\text { digestive } \\
\text { gland, } \\
\text { gonads, } \\
\text { mantle and } \\
\text { labial } \\
\text { palps }\end{array}$ & $\begin{array}{l}0,10,25,40 \text { and } \\
50\end{array}$ \\
\hline $\begin{array}{l}\text { Rickettsia-like } \\
\text { organism }\end{array}$ & $\begin{array}{l}\text { Genera of nonmotile, Gram-negative, } \\
\text { nonspore-forming, highly pleomorphic } \\
\text { bacteria that can be present as cocci }(0.1 \\
\mu \mathrm{m} \text { in diameter), rods }(1-4 \mu \mathrm{m} \text { long), or } \\
\text { thread-like }(10 \mu \mathrm{m} \text { long). }\end{array}$ & Gills & $\begin{array}{l}0,10,25,40 \text { and } \\
50\end{array}$ \\
\hline Urastoma sp. & $\begin{array}{l}\text { Urostomidae, } \\
\text { turbellarian parasites. }\end{array}$ & $\begin{array}{l}\text { Gills, } \\
\text { digestive } \\
\text { gland and } \\
\text { gonads }\end{array}$ & $\begin{array}{l}0,10,25,40 \text { and } \\
50\end{array}$ \\
\hline
\end{tabular}

Table 4. Indicators and the total number of alterations and pathogens in parameters observed in oyster (Crassostrea gasar) tissues exposed to different salinities after 0, 5, 15 and 30 days of exposure.

\begin{tabular}{|c|c|c|c|c|c|c|c|}
\hline \multirow[b]{2}{*}{ Indicators } & \multirow[b]{2}{*}{ Parameter } & \multicolumn{6}{|c|}{ Salinity $\left(\mathrm{gL}^{-1}\right)$} \\
\hline & & $\begin{array}{l}\begin{array}{l}\text { Control } \\
(\mathrm{n}=6)\end{array} \\
\end{array}$ & $\begin{array}{l}0 \\
(n=18)\end{array}$ & $\begin{array}{l}10 \\
(n=18)\end{array}$ & $\begin{array}{l}25 \\
(n=18)\end{array}$ & $\begin{array}{l}40 \\
(n=18)\end{array}$ & $\begin{array}{l}50 \\
(n=18)\end{array}$ \\
\hline $\begin{array}{l}\text { Stress indicator } \\
\text { cell }\end{array}$ & Brown cells & 925 & 2009 & 9928 & 7180 & 9710 & 4743 \\
\hline \multirow{3}{*}{$\begin{array}{l}\text { Tissue } \\
\text { alterations }\end{array}$} & Hyperplasia of gill epithelium & 0 & 2 & 32 & 34 & 24 & 21 \\
\hline & Gland tissue cell hypertrophy & 4 & 2 & 19 & 10 & 19 & 0 \\
\hline & Nematopsis sp. & $11^{\mathrm{ab}}$ & $27^{\mathrm{ab}}$ & $237^{\mathrm{ab}}$ & $220^{\mathrm{ab}}$ & $97^{\mathrm{b}}$ & $227^{\mathrm{a}}$ \\
\hline \multirow[t]{2}{*}{ Pathogen } & Rickettsia-like organism & $130^{\mathrm{ab}}$ & $321^{\mathrm{ab}}$ & $1044^{\mathrm{ab}}$ & $1101^{\mathrm{a}}$ & $1026^{\mathrm{ab}}$ & $389^{\mathrm{b}}$ \\
\hline & Urastoma sp. & 1 & 4 & 9 & 10 & 19 & 2 \\
\hline
\end{tabular}




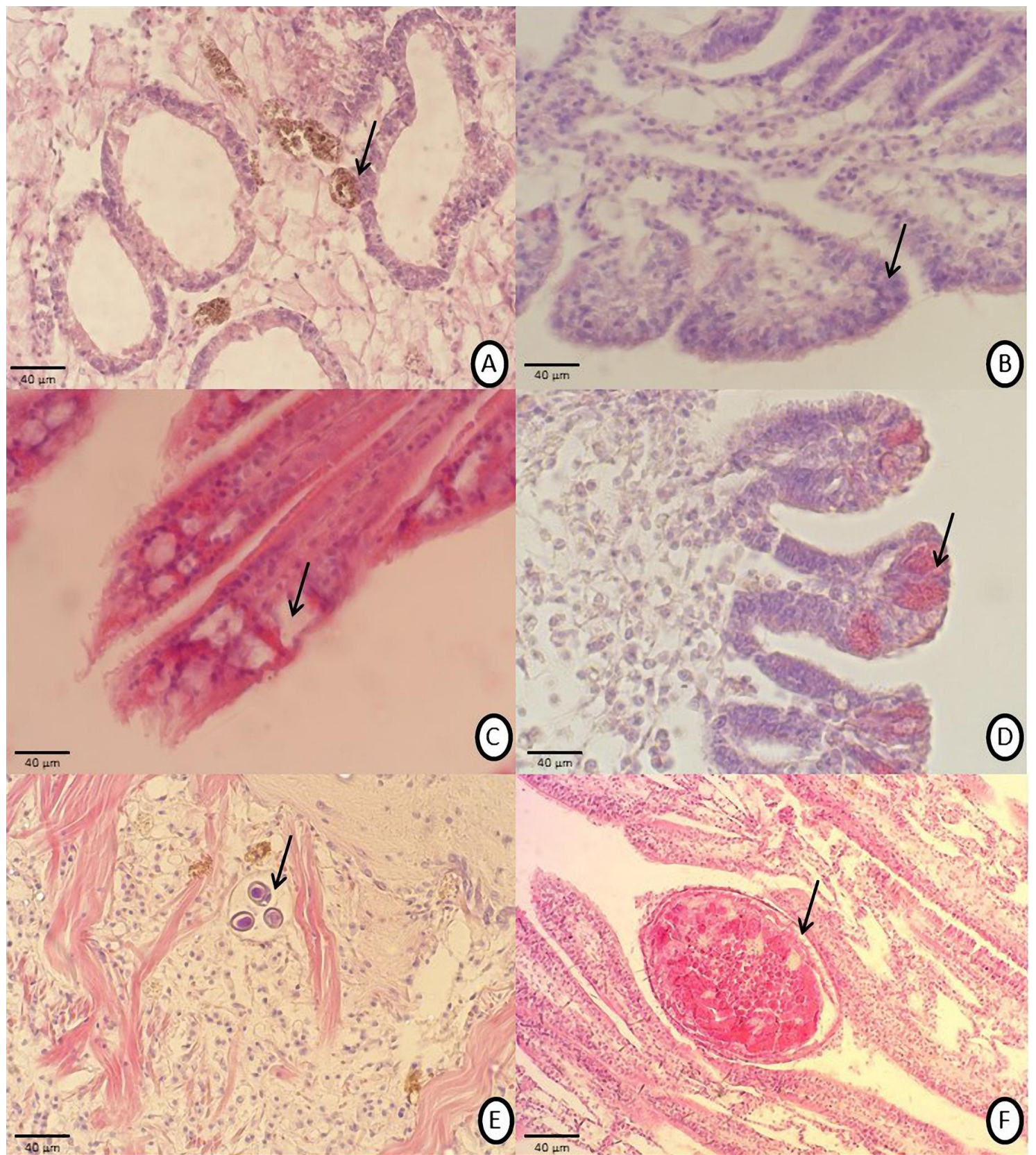

Figure 2. Tissue alterations and pathogen found in oysters exposed to different salinities. A: Brown cells; B: Hyperplasia of gill epithelium; C: Hypertrophy of gill mucous cell; D: Rickettsia-like organism; E: Nematopsis sp.; F: Urastoma sp.

\section{DISCUSSION}

Even some of the world's most aquacultured species may encounter problems related to the reduction of salinity in cultivation areas. For example, according to Ellard et al. (2004), Crassostrea gigas cultivated in the bays of George and Moulting, Australia suffered $90 \%$ mortality after a period of rainfall in the summer when salinity was reduced to $2 \mathrm{gL}^{-1}$ for 10 consecutive days. Similarly, La Peyre M. K. et al. (2013) noted that nearly $100 \%$ of the oysters Crassostrea virginica cultivated in the Breton Sound estuary in
Louisiana died when they were exposed to salinities below $5 \mathrm{gL}^{-1}$ during the summer months. Based on these findings, it is possible to say that in the present study $C$. gasar presented high tolerance to low salinities. The individuals tested survived at salinities below $2 \mathrm{gL}^{-1}$ for up to approximately 13 days and, on average, for 6 months in a salinity of 5 $\mathrm{gL}^{-1}$.

In addition to estuarine areas, oysters can also be cultivated in hypersaline waters. For instance, there are records of commercial enterprises installed in hypersaline lagoons (Ferreira et al. 2009, Largier et al. 1997), in subtropical seawater fish 
ponds with salinity above $40 \mathrm{gL}^{-1}$ (Hughes-Games 1977), or in abandoned saline ponds (HughesGames 1977, King 1977). Our results suggest that C. gasar could survive for long periods (for up to approximately 100 days) in waters with up to $40 \mathrm{gL}$ 1, occasionally tolerating up to $50 \mathrm{gL}^{-1}$ for short periods, which could enable it to be cultivated in temporarily hypersaline environments.

According to La Peyre M. K. et al. (2013), the high mortality rate of oysters of the genus Crassostrea exposed to extreme salinities is related to the inability of these animals to control plasma osmolality for long periods, and to the prolonged closure of the valves during these events. Thus, it is probable that the rapid mortality of the oysters tested (in salinities below 2 and greater than $50 \mathrm{gL}^{-1}$ ) occurred due to a process of metabolic acidosis. As stated by Lombardi et al. (2013), when exposed in intolerable salinity ranges, oysters close their valves for an indeterminate time, causing the accumulation of carbon dioxide in the tissues, which promotes respiratory acidosis, eventually leading to the death of the animal.

In relation to the ranges considered "Tolerable" (between 2.1 and 3.9 and between 40 and $50 \mathrm{gL}^{-1}$ ) and "Optimum" (from 4 to $40 \mathrm{gL}^{-1}$ ), some differences were observed when our results were compared to those of Funo et al. (2015), who also studied the effects of salinity on C. gasar. Funo et al. (2015) recorded that the C. gasar tolerance range to salinity extended from 10 to $50 \mathrm{gL}^{-1}$, but better results were achieved at $25 \mathrm{gL}^{-1}$. Additionally, Wakamatsu (1973) and Pereira O. M. et al. (2001) concluded that $C$. gasar tolerates salinities between 8 and $34 \mathrm{gL}^{-1}$ but with a higher survival rate between 15 and $25 \mathrm{gL}^{-1}$. The primary difference between the present work and these previous studies is the total duration of the experiment. Even without access to any kind of exogenous food, the animals in the present study were able to survive within the "Optimum" range of salinity tolerance for periods longer than 6 months, with a portion even surviving for a year under these conditions. Although unexpected, this great tolerance to prolonged fasting probably is related to anabolism and the storage of energy reserves. Oysters store glycogen in their tissues, and when necessary, degrade it, generating energy from glucose (LI et al. 2007).

Another difference in relation to the results obtained in the present study was the absence of a causal link between salinity and the only two tissue alterations identified in the oysters analysed (hyperplasia and gill hypertrophy). These results differ from those found by Knowles et al. (2014), who identified several tissue alterations resulting from exposure to reduced salinities (up to $3 \mathrm{gL}^{-1}$ ) in C. gigas from northwestern Tasmania. Among the alterations identified by Knowles et al. (2014) were: intracytoplasmic vacuolization and haemocytes infiltration in the digestive tract, erosion of the mantle, expansion of renal intracellular spaces, gonadal necrosis, and Leydig cells. Additionally, Winstead J. T. (1995) found that C. virginica presented atrophy of the digestive gland due to valve closure after exposure to low salinities in Apalachicola Bay, Florida.

Among the anomalies identified in the present study, only the presence of the parasite Nematopsis sp. and RLO bacteria exhibited statistically significant differences between certain treatments. It is known that Nematopsis sp. is usually found in the gills, mantle, digestive gland and labial palps and that when in low densities, this parasite does not cause significant damage to the oyster tissues (Cremonte et al. 2005, Winstead J. T. et al. 2004). However, Sabry et al. (2007) found that the high prevalence of Nematopsis sp. in Crassostrea rhizophorae (affecting from 60 to $100 \%$ of organs) led to the occurrence of haemocyte infiltration. Other damage caused by Nematopsis sp. can be the destruction of connective tissue (Boehs et al. 2010). However, the occurrence of Nematopsis sp. in the oysters analysed in the present study was too low to enable us to identify any specific lesions that could be associated with the presence of this parasite. To the best of our knowledge, there are no studies that relate the effects of salinity with the presence of Nematopsis sp. in oysters.

Conversely, several studies conducted with other species of bivalves reported that after an increase in environmental salinity, there was increase in RLO colonization. This phenomenon was described in cultivated $C$. gigas exposed to 29 $\mathrm{gL}^{-1}$ in Alaska (MEYERS et al. 1990) and in the cockle Tegillarca granosa exposed to $30 \mathrm{gL}^{-1}$, in Yueqing Bay, China (ZEWEN et al. 2012). In our study, the presence of RLO was recorded in all treatments, with the exception of $50 \mathrm{gL}^{-1}$, in which there was a trend of these organisms decreasing in the tissues between the analysed periods. However, the absence of a defined standard did not confirm the hypothesis that the presence of RLO was related to salinity.

Crassostrea gasar is an euryhaline oyster that can survive for long periods in waters with salinities between 4 and $40 \mathrm{gL}^{-1}$, even without access to food. Additionally, for short periods, these oysters can tolerate salinities as extreme as 2.1 and $50 \mathrm{gL}^{-1}$. No histological changes were identified 
that could be correlated with the exposure of $C$. gasar to sub-optimal or even extreme salinities.

\section{ACKNOWLEDGEMENTS}

We thank the National Council for Scientific and Technological Development (CNPq) for granting funding to Antonio Ostrensky (process number 381091/2014-7); and for awarding the Ph.D. scholarship of Aline Horodesky, without which the present research would not have been possible.

RESUMO: A salinidade da água está entre os fatores de maior influência na distribuição, abundância, crescimento e sobrevivência de Crassostrea gasar, um importante recurso aquícola cultivado em ambientes estuarinos em diversas regiões do mundo. $\mathrm{O}$ objetivo desse trabalho foi avaliar os efeitos da salinidade sobre a sobrevivência e nos tecidos de $C$. gasar exposta a diferentes salinidades, em condições laboratoriais. Foram realizados dois experimentos com ostras adultas provenientes de cinco fazendas marinhas localizadas na baía de Guaratuba, Brasil. No experimento 1, que foi realizado com o propósito de avaliar as taxas diárias de sobrevivência, as ostras foram submetidas à aclimatação gradual a salinidades variando de 0 a $65 \mathrm{gL}^{-1} \mathrm{e}$ mantidas em laboratório, sem alimentação, por até 365 dias. No experimento 2 , as ostras foram expostas a salinidades de 0 a $50 \mathrm{gL}^{-1}$ por até 30 dias, sem alimentação, para avaliação de possíveis alterações histológicas provocadas pela salinidade. Foram identificadas três faixas de tolerância de $C$. gasar à salinidade: Ótima (entre 4 e $40 \mathrm{gL}^{-1}$ ), Tolerável (entre 2,1 e 3,9 e entre 41 e $50 \mathrm{gL}^{-1}$ ) e Intolerável (menor que 2 e maior que $50 \mathrm{gL}^{-1}$ ). Não foram encontradas evidências de alterações histológicas em função da exposição das ostras às diferentes salinidades.

PALAVRAS-CHAVE: Estuário. Histologia. Mortalidade. Ostreicultura.

\section{REFERENCES}

AFINOWI, M. A. The mangrove oyster, Crassostrea gasar cultivation and potential in the Niger Delta (Nigeria). Nigerian Institute for Oceanography and Marine Research, v. 14, p. 1-13,1984.

AREIAS, D. L. L. Efeito da salinidade e temperatura no assentamento da ostra Crassostrea gasar (Adanson, 1757) e indução da desova de ostras Crassostrea gigas (Thunberg, 1795). 2012, 49 f. Dissertação (Mestrado em Ciências) - Curso de Pós-Graduação em Ciências, Universidade do Porto, Cidade do Porto, 2012.

BALDAN, A. P.; BENDHACK, F. Maricultura sustentável no litoral do Paraná- Brasil: Atualidades e perspectivas. Revista Acadêmica de Ciências Agrárias e Ambiental, v. 7, n. 1, p. 491-497, out. 2009.

BEHMER, O.A.; TOLOSA, E. M. C.; FREITAS-NETO, A. G. Manual de técnicas para histologia normal e patológica. 1 . ed. São Paulo: EDART/USP, 1976. 456 p.

BOEHS, G.; VILLALBA, A.; CEUTA, L. O.; LUZ, J. R Parasites of three commercially exploited bivalve mollusc species of the estuarine region of the Cachoeira river (Ilhéus, Bahia, Brazil). Journal of Invertebrate Pathology, v. 103, p. 43-47, jan. 2010.

BROWN, J. R.; HARTWICK, E. B. Influences of temperature, salinity and available food upon suspended culture of the Pacific oyster, Crassostrea gigas: I. Absolute and allometric growth. Aquaculture, v. 70, n. 1, p. 231-251, may 1988.

CASAS, S.; WALTON, W.; CHAPLIN, G.; RIKARD, S.; SUPAN, J; LA PEYRE, J. Performance of oysters selected for dermo resistance compared to wild oysters in northern Gulf of Mexico estuaries. Aquaculture Environment Interactions, v. 9, n. 1, p. 169-180, may 2017. 
CASTILHO-WESTPHAL, G. G.; OSTRENSKY, A. Temporal variation in larval abundance of the mangrove oyster Crassostrea sp. in an estuary of southern Brazil. Archives of Veterinary Science, v. 22, n. 1, p. 1-22, jun. 2017.

CREMONTE, F.; BALSEIRO, P.; FIGUERAS, A. Occurrence of Perkinsus olseni (Protozoa: Apicomplexa) and other parasites in the venerid commercial clam Pitar rostrata from Uruguay, southwestern Atlantic Coast. Diseases of Aquatic Organisms, v. 64, n. 1, p. 85-90, apr. 2005.

DOWNS, C. A.; KRAMARSKY-WINTER, E.; WOODLEY, C. M.; DOWNS, A.; WINTERS, G.; LOYA, Y.; OSTRANDER, G. K. Cellular pathology and histopathology of hypo-salinity exposure on the coral Stylophora pistillata. Science of the total environmental, v. 407, n. 1, p. 4838-4851, aug. 2009.

ELLARD, K; PYECROFT, P; HANDLINGER, J. Oyster Mortalities in the Georges Bay Marine Farming Development Plan Area, Austrália: DPIWE Tasmânia. Report February 2004.

FERREIRA, J; SEQUEIRA, A; HAWKINS, A; NEWTON, A; NICKELL, T; PASTRES, R; FORTE, J; BODOY, A; BRICKER, S Analysis of coastal and offshore aquaculture: application of the FARM model to multiple systems and shellfish species. Aquaculture, v. 289, n. 1, p. 32-41, jul. 2009.

FUNO, ICSA; ANTONIO, I. G. ; MARINHO, Y. F.; GÁLVEZ, A.O Influência da salinidade sobre a sobrevivência e crescimento de Crassostrea gasar. Boletim do Instituto de Pesca, v. 41, n. 4, p. 837-847, jul. 2015.

GALTSOFF, O. S. The american oyster Crassostrea virginica Gmelin. US Government Printing Office. 1964.

GUZENSKI, J. Comparação do efeito da salinidade e concentração de substâncias húmicas no crescimento de Crassostrea rhizophorae (Guilding, 1828). 1996, 52 f. Dissertação (Mestrado em Ciências) - Curso de PòsGraduação em Ciências Agrárias, Universidade Federal de Santa Catarina, Florianópulis. 1996.

HUGHES-GAMES, W. Growing the Japanese oyster (Crassostrea gigas) in subtropical seawater fish ponds. I. Growth rate, survival and quality index. Aquaculture, v. 11, n. 3, p. 217-229, jul. 1977.

KING, M. G. Cultivation of the Pacific oyster (Crassostrea gigas) in a non-tidal hypersaline pond. Aquaculture, v. 11, n. 2, p. 123-136, jun. 1977.

KNOWLES, G.; HANDLINGER, J. JONES, B.; MOLTSCHANIWSKYJ, N. Hemolymph chemistry and histopathological changes in Pacific oysters (Crassostrea gigas) in response to low salinity stress. Journal of Invertebrate Pathology, v. 121, n. 1, p. 78-84, sep. 2014.

LA PEYRE, M. K.; EBERLINE, B. S.; SONIAT, T. M.; LA PEYRE, J. Differences in extreme low salinity timing and duration differentially affect eastern oyster (Crassostrea virginica) size class growth and mortality in Breton Sound, LA. Estuarine, Coastal and Shelf Science, v. 135, n. 1, p. 146-157, dec. 2013.

LA PEYRE, M. K. N.; VOLETY, A. K.; TOLLEY, G. S. ; LA PEYRE, J. F. Environmental significance of freshets in reducing Perkinsus marinus infection in eastern oysters Crassostrea virginica: potential management applications. Marine Ecology Progress Series, v. 248, n. 1, p. 165-176, feb. 2003.

LAPÈGUE, S; BOUTET, I; LEITÃO, A; HEURTEBISE, S; GARCIA, P; THIRIOTUIEVREUX, C; BOUDRY, $\mathrm{P}$ Trans-Atlantic distribution of a mangrove oyster species revealed by $16 \mathrm{~S}$ mtDNA and karyological analyses. Biological Bulletin, v. 202, n. 1, p. 232-242, jun. 2002.

LARGIER, J.; HOLLIBAUGH, J. T.; SMITH, S. Seasonally hypersaline estuaries in Mediterranean-climate regions. Estuarine, Coastal and Shelf Science, v. 45, n. 1, p. 789-797, dec. 1997. 
LEGAT, J. F. A; PUCHNICK-LEGAT, A.; GOMES, CHADM; SÜHNEL, S.; MELO, C. M. R. D. Effects of salinity on fertilization and larviculture of the mangrove oyster, Crassostrea gasar in the laboratory. Aquaculture, v. 468, n. 1, p. 545-548, feb. 2017.

LEVINTON, J; DOALL, M; RALSTON, D; STARKE, A; ALLAM, B Climate change, precipitation and impacts on an estuarine refuge from disease. PLoS ONE, v. 6, n. 1, p. 1-8, apr. 2011.

LI, Y; QIN, J. G.; ABBOT, C. A; LI, X.; BENKENDORFF, K. Synergistic impacts of heat shock and spawning on the physiology and immune health of Crassostrea gigas an explanation for summer mortality in Pacific oysters. American Journal of Physiology Regulatory Integrative, v. 293, n. 1, p. 2353-2362, dec. 2007.

LOMBARDI, S.A.; HARLAN, N. P. ; PAYNTER, K.T. Survival, acid-base balance, and gaping responses of the Asian oyster Crassostrea ariakensis and the eastern oyster Crassostrea virginica during clamped emersion and hypoxic immersion. Journal of Shellfish Research, v. 32 p. 409-415, aug. 2013.

LOOSANOFF, V. L. Behavior of oysters in water of low salinities. Pages 135-151. Proceedings of the National Shellfisheries Association. 1953.

LOPES, GR; GOMES, CHADM; TURECK, CR; MELO, CMR Growth of Crassostrea gasar cultured in marine and estuary environments in Brazilian waters. Pesquisa Agropecuária Brasileira, v. 48, n. 8 p. $975-$ 982, aug. 2013.

MELLO, G. L. Policultivo de ostras e camarões marinhos em viveiros de aquicultura. FAEPE p. 23,2007.

MÉTHÉ, D. C. Eastern oyster, Crassostrea virginica: Productivity and physiology under varying temperature and salinity conditions. 2015. 148 f. Thesis (Doctor of Philosophy) - Curso de Pós-Graduação em Ciências, Universidade do Porto, Cidade do Porto, 2012. Department of Health Management Atlantic Veterinary College. University of Prince Edward Island, Edward Island. 2015.

MEYERS, TR; SHORT, S; EATON, W Summer mortalities and incidental parasitisms of cultured Pacific oysters in Alaska. Journal Of Aquatic Animal Health, v. 2, n. 1, p. 172-176, sep. 1990.

MORALES, J. C. Acuicultura marina animal. Madrid Mundi-Prensa. 1986.

PARADA, JM; MOLARES, J; OTERO, X Multispecies mortality patterns of commercial bivalves in relation to estuarine salinity fluctuation. Estuaries and Coasts, v. 35, n. 1, p. 132-142, jul. 2012.

PEREIRA, C. S. A cultura de mexilhões na baía de Guanabara e suas implicações para a Saúde Pública Contexto político-social e microbiológico. Pesquisa Veterinaria Brasileira, v. 27, n. 2, fev. 2003.

PEREIRA, O. M; MACHADO, I. C; HENRIQUES, M. B; GALVÃO, M. S. N; YAMANAKA, N. Avaliação do estoque da ostra Crassostrea brasiliana em rios e gamboas da região estuarino-lagunar de Cananéia (São Paulo, Brasil). Boletim do Instituto de Pesca, v. 27, n. 1, p. 85-95, mar. 2001.

PIERCE, SK Invertebrate cell volume control mechanisms: a coordinated use of intracellular amino acids and inorganic ions as osmotic solute. The Biological Bulletin, v. 163, n. 1, p. 405-419, jul. 1982.

POTTER, IC; CHUWEN, BM; HOEKSEMA, SD; ELLIOTT, M The concept of an estuary: a definition that incorporates systems which can become closed to the ocean and hypersaline. Estuarine, Coastal and Shelf Science, v. 87, n. 3, p. 497-500, apr. 2010.

SABRY, R. C; GESTEIRA, T. C. V; BOEHS, G. First record of parasitism in the mangrove oyster Crassostrea rhizophorae (Bivalvia: Ostreidae) at Jaguaribe River estuary - Ceará, Brazil. Brazilian Journal of Biology, v. 67, n. 4, p. 755-758, nov. 2007. 
SHELFORD, VE Animal comunities in temperature America as illustrated in the Chicago region. Bulletim of the Geographical Society of Chicago, v. 31, n. 1, p. 120-123, out. 1914.

SHUMWAY, SE Natural environmental factors. Pages 467-513 in Kennedy VS, Newell RIE, Eble AF, eds. The Eastern Oyster Crassostrea virginica. Maryland: Maryland Sea Grant College. 1996.

SIDDALL, SE Dispersal and recruitment of tropical mussel larvae as affected by temperature and salinity. Journal of Shellfish Research, v. 2, n.1, p.106-107, mar. 1982.

TOLLEY, SG; VOLETY, AK; SAVARESE, M; WALLS, LD; LINARDICH, C; EVERHAM, IEM Impacts of salinity and freshwater inflow on oyster-reef communities in Southwest Florida. Aquatic Living Resources, v. 19, n. 4, p.371-387, oct. 2006.

VILANOVA, MFV; CHAVES, EMB. Contribuição para o conhecimento da viabilidade do cultivo de ostrado-mangue, Crassostrea rhizophorae (Guilding, 1828) (Mollusca:Bivalvia), no estuário do rio Ceará, Ceará, Brasil. Arquivos de Ciência Marinha, v. 27, n.1, p.111-125, dec. 1988.

WAKAMATSU, T A ostra de Cananéia e seu cultivo. Instituto Oceanográfico. 1973.

WELLS, HW The fauna of oyster beds, with special reference to the salinity factor. Ecological Monographs v.31, n.1, p.239-266, feb. 1961.

WIDMAN, JC; MESECK, SL; SENNEFELDER, G; VEILLEUX, DJ Toxicity of Un-ionized Ammonia, Nitrite, and Nitrate to Juvenile Bay Scallops, Argopecten irradians irradians. Archives of environmental contamination and toxicology, v. 54, n.3, p.460-465, apr. 2008.

WINSTEAD, JT Digestive tubule atrophy in Eastern oyster, Crassostrea virginica (Gmelin, 1971) exposed to salinity and starvation stress. Journal Shellfish Research, v. 14, n. 1, p.105-111, may 1995.

WINSTEAD, JT; VOLETY, AK; TOLLEY, SG Parasitic and symbiotic fauna in oyster (Crassostrea virginica) collected from the Caloosahatchee River and Estuary in Florida. Journal Shellfish Research, v. 23, n.1, p.831840, apr. 2004.

ZEWEN, Z; TING, X; XINZHONG, W; LIUJI, W; QINGGUO, M; JIAQING, H. Rickettsia-like organism infection associated with mass mortalities of blood clam, Tegillarca granosa, in the Yueqing Bay in China. Acta Oceanologica, v. 31, n. 1, p. 106-115, jan. 2012. 